\title{
CLINICAL FEATURES OF THE COURSE OF CHRONIC EPSTEIN-BARR VIRAL INFECTION DEPENDING ON THE TYPE OF IMMUNE REACTION OF ORGANISM
}

\author{
Tatiana Liadova \\ Department of General and Clinical Immunology and Allergology \\ V. N. Karazin Kharkov national university \\ 4 Svobody sq., Kharkiv, Ukraine, 61022 \\ tanya-07-07@mail.ru
}

\begin{abstract}
The results of the study of the main regulatory cytokines levels in patients with chronic forms of EBV-infection (CEBV) are presented the work.

Aim of research. To establish the types of immune reaction for prognostication of the clinical course of disease in patients with chronic forms of EBV-infection on the base of the analysis of multidirectional synthesis dynamics of anti-inflammatory cytokines (IL-1 $\beta$, TNF- $\alpha$, IL-6), regulatory IL-2 and anti-inflammatory cytokines (IL-4 and IL-10).

Methods. The research oт the study of the main cytokines levels by IEA method in the disease dynamics included patients with EBV-infection $(n=80)$. The serum concentrations of studied cytokines: IL-1 $\beta$, TNF- $\alpha$, IL-6, IL-2, IL-4, IL-10 were determined using test-systems by LTD "Protein outline" (Saint Petersburg, Russia), using the producer's instruction, by sIEA.

Statistical analysis of the results of research was carried out using the program Statistika 6.0 for Windows (Stat Soft Inc, USA).

Results. The analysis of cytokine profile dynamics in patients with EBV-infection allowed reveal the multidirectional changes of synthesis of studied anti-inflammatory and proinflammatory cytokines that became a base for establishing of two types of immune reaction: dissociative and hyporeactive. Dissociative type was characterized with the low parameters of anti-inflammatory cytokines and regulatory IL-2 on the background of moderately increased values of anti-inflammatory cytokines, whereas the hyporeactive type was characterized with the low concentrations of all studied parameters.

Conclusions. The received results of researches prove the existence of cytokine imbalance at EBV-infection. The established types of immune reaction testify to the inadequate cellular-humoral reactivity of organism under conditions of EBV prolonged persistency that is manifested by inclination to suppression of cellular-mediated and intensification of humoral mechanisms of immune response and is reflected in clinical-biochemical manifestations of disease that results in prolonged wavy course.

Just the functional imbalance of immunity links to the priority of Tx2 type, which biological effects are directed on the limitation of intensity and prevalence of inflammatory process in different organs, favors the prolongation of viral persistency.

Keywords: immunity, cytokines, types of immune reaction, chronic VEB-infection.
\end{abstract}

\section{Introduction}

In last years it was proved, that the initiators of immune response in human organism are cytokines that not only actively participate in formation of regulatory defense reactions but also provide homeostasis of organism in whole $[1,2]$. Imbalance in the system of cytokine regulatory chain is a node link of immune disorders at EBV-infection.

It was established, that EBV-infection and HIV-infection is a disease of immune system, characterized with prolonged persistency of virus. This virus is a lymphotropic agent, causing the development of the lymphoproliferation and immune deficiency syndromes. Only in the case of infectious mononucleosis (IM) the one of main persistency places are B-lymphocytes that essentially influence the state of humoral immunity link, causing immune suppressive states. In connection with these properties of EBV immune system loses the ability to control the infectious process, induced by this virus or caused by the present outside microflora [2-4].

Prognostication of the results of EBV-infection depends on the presence and intensity degree of immune dysfunction, genetic predisposition to the one or another EBV-associated diseases and also on the series of external factors (stresses, infections, surgical interventions, unfavorable influence of environment), that injury the immune system. The scientists established that EBV has the large number of genes that give it a possibility to avoid the human immune system to certain extent. Particularly, EBV produces proteins - analogues of human interleukins and their receptors 
that change the immune response [5]. In the period of active reproduction the virus produces IL-10-like protein that suppresses T-cellular immunity, function of cytotoxic lymphocytes, macrophages, disturbs the all stages of the natural killers functioning. The other viral protein can block the activity of cells-killers by inhibition of interleukin-12. At the same time EBV has a high mutable ability that allows it avoid for some time the influence of specific immunoglobulins (produced to the virus before its mutation) and the cells of the host's immune system. Thus, the EBV reproduction in human organism can be the cause of appearance of secondary immunodeficiency [6-17].

The disturbance of balance between the main regulatory cytokines obviously can lead to prolonged EBV persistency, often relapses and progressing of disease. From these positions EBV-infection can be considered as "unbalanced cytokinemia" [3-5].

The researchers think that predominant participation of cytokines, produced by Th-2-lymphocytes is associated with prolonged viral persistency and chronization of process, whereas the activation of Th-1 type - with spontaneous recovery at the acute EBV forms [18-21]. That is why the study of data about the production of main regulatory cytokines with establishing of the type of immunologic reaction at EBV-infection is topical.

\section{Aim of research}

To establish the types of immune reaction for prognostication of the clinical course of disease in patients with chronic forms of EBV-infection on the base of the analysis of multidirectional synthesis dynamics of anti-inflammatory cytokines (IL-1 $\beta$, TNF- $\alpha$, IL-6), regulatory IL-2 and anti-inflammatory cytokines (IL-4 and IL-10).

\section{Materials and methods}

The work was carried out at the department of general and clinical immunology and allergology of the medical faculty of Kharkov national university, named after V. N. Karazin and clinical bases of the department of Regional clinic infectious hospital of city Kharkov and MMI "City polyclinic № 6”, Kharkov in 2009-2015.

For realization of the set aim 183 patients with chronic course of EBV-infection (CEBV) were examined. The age of examined patients was in diapason 19-57 years (mean age 33,1 $\pm 11,7$ years). Women were $55,7 \%(n=102)$, men $-44,3 \%(n=81)$ (women-men ratio 1,2:1,0).

Based on the aim, the studied group included patients with the different immunopathological and immunodeficiency disease: serous meningitis $(n=8)$, chronic tonsillitis $(n=32)$, nonspecific lymphadenopathy $(n=48)$, prolonged subfebrility $(n=54)$, reactive arthritis $(n=16)$, chronic fatigue syndrome $(n=25)$. From this category of patients with CEBV-infection was separated the group of patients $(n=80)$, in whom the level of proinflammatory (IL-1 $\beta$, IL-6, TNF- $\alpha$ ), anti-inflammatory (IL-4, IL-10) cytokines and regulatory IL-2 production was studied.

The group of comparison included 20 clinically healthy young people without the signs of acute or any chronic pathology, among which 16 were examined as to the EBV markers, mean age $24,1 \pm 3,2$ years. In anamnesis of their life were absent the data about IM and "serologic profile" was characterized with the presence of EBNA - Ig G only and absence of EBV DNA in the blood plasma and saliva. All patients with IM and lymphadenopathy necessarily underwent bacteriological study of smear from nasopharynx as to pathogenic flora and diphtheria.

The complex of examination of patients included clinical analysis of blood, revelation of atypical mononuclears, determination of specific Ig to EBV by the method of solid-phase immune-enzyme analysis (sIEA), revelation of EBV DNA by the method of polymerase chain reaction (PCR) in the blood and saliva, activity of asparaginic and alanine transaminases (ASAT, ALAT), lactate dehydrogenase (LDG), and creatine phosphokinase (CPG), content of C-reactive protein (CRP), fibrinogen in the dynamics of disease.

For verification of diagnosis the complex of serologic and molecular-genetic studies was carried out besides the general blood analysis. Heterogenetic test in Hoff-Bauer (HB) modification was applied as a screen express-analysis of blood as to the presence of EBV-infection (Chireshkina N. M., 1973).

Specific antiviral antibodies (VCA-IgM, EA-IgM and EBNA-IgG) in the blood serum were determined by sIEA by the sets, made by «IBL» (Germany) and "Vector-Best" (RF) according to 
the given instructions. For differential diagnostics several patients underwent serologic examination as to the herpes simplex virus of $1+2$ type (HSV-1+2), cytomegalovirus (CMV), toxoplasma, hepatitis viruses (A, B and C), HIV. For that the following test-systems were correspondingly used for sIEA: anti-CMV-IgM, anti-Toxo-IgM, anti-HVA-IgM, HBsAg, anti-HBc-total and anti-HIV-1+2 total made by: SPO "Diaprof” (Ukraine), "Diagnostic systems" (Russia), «Vector-Best» (RF), «BL» (Germany).

Molecular-genetic studies included the determination of EBV replicative activity on the base of revelation of EBV DNA in the blood serum by the qualitative method of PCR using test-systems, made by SPF “Litech" (Russia).

The serum concentrations of studied cytokines: IL-1 $\beta$, TNF- $\alpha$, IL-6, IL-2, IL-4, IL-10 were determined using test-systems by LTD "Protein outline" (Saint Petersburg, Russia), using the producer's instruction, by sIEA. The material of the study was the blood serum of patients with CEBV, taken in the period of aggravation of disease. The study included 80 patients with CEBV.

Technical realization of the analyses was carried out in the clinical-diagnostic laboratory of region clinic infectious hospital of city Kharkov (RCIH), medical laboratory "SINEVO".

Statistical processing of the results was carried out using the program Statistika 6.0 for Windows (Stat Soft Inc, USA) on personal computer with processor Pentium II Celeron 850 PPGA. The mean arithmetical (M), mean square deviation $(\sigma)$, mean error of mean arithmetical $(m)$ were calculated for each variational series. The assessment of reliability of the mean values (p) was carried out using Student-Fisher criterion $(t)$. The divergences were considered as reliable ones at the value $p<0,05$. The data, received at examination of this category of patients, were presented in the article as absolute values.

\section{Results of research}

Having analyzed the cytokine profile dynamics in patients with EBV-infection we revealed the multidirectional changes of synthesis of studied anti-inflammatory and proinflammatory cytokines that became a base for establishing of two types of immune reaction: dissociative and hyporeactive.

The data about the reveled types of immune reaction are presented on the Fig. 1, $\boldsymbol{a}, \boldsymbol{b}$.
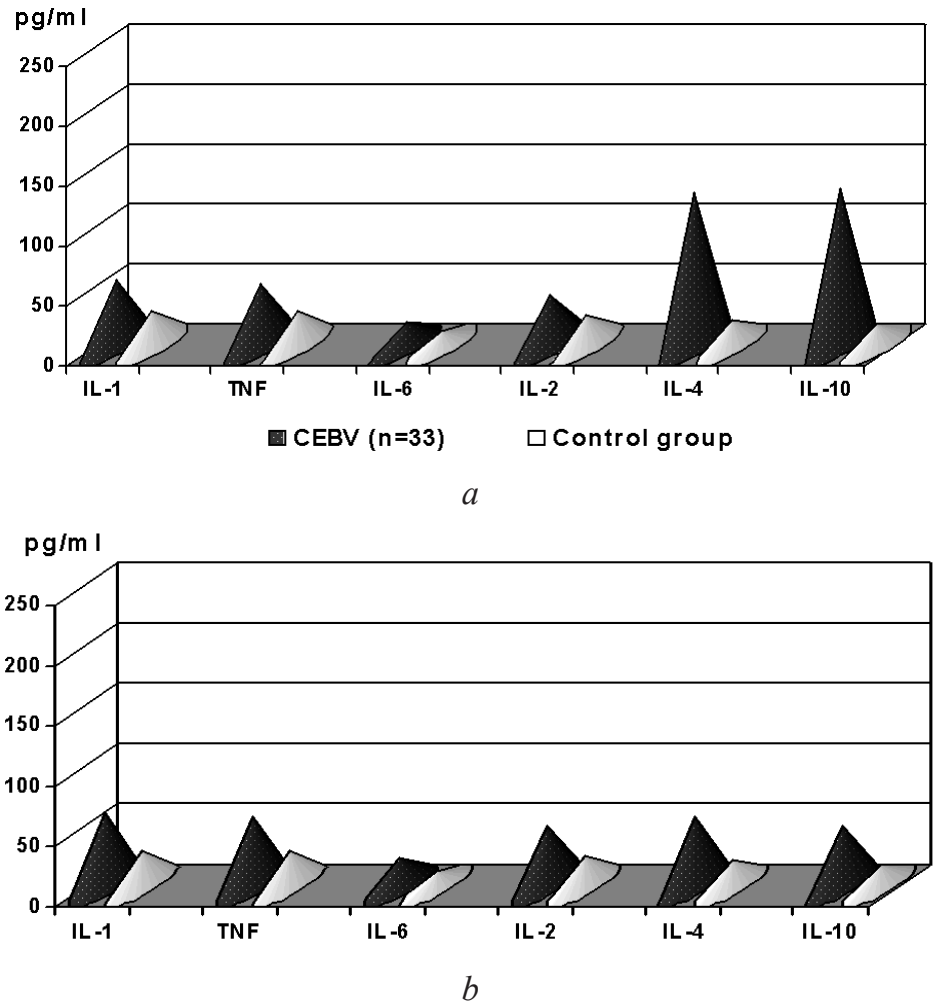

Fig. 1. Types of immune reaction in patients with CEBV-infection: $a$-dissociative type; $b$-hyporeactive type 
The results of analysis of the influence of established types of immune reaction on CEBV clinical course and of the study of the parameters of mean duration of the main clinical symptoms in patients with the different types of immune reaction are presented in the Table $\mathbf{1 .}$

Table 1

Duration of the main clinical symptoms depending on type of immune reaction in patients with CEBV $(n=80)$

\begin{tabular}{ccc}
\hline Clinical symptoms & $\begin{array}{c}\text { Duration of clinical symptoms at the different types of immune reaction (M } \pm \mathbf{m}) \text { days } \\
\text { Hyporeactive type (1 group) } \mathbf{n}=\mathbf{3 3}\end{array}$ & $\begin{array}{c}\text { Dissociative type (2 group) } \mathbf{n}=\mathbf{4 7} \\
\text { General weakness }\end{array}$ \\
\hline Arthralgia, myalgia & $5,6 \pm 1,2$ & $10,1 \pm 1,3^{*}$ \\
Peripheral lymphodenopathy & $4,6 \pm 0,9$ & $8,9 \pm 1,0^{*}$ \\
Subfebrility & $4,8 \pm 1,1$ & $9,7 \pm 1,2^{*}$ \\
Hepatolineal syndrome & $5,9 \pm 1,8$ & $10,4 \pm 1,4^{*}$
\end{tabular}

Note: $*-p<0,05$ between parameters of 1 and 2 group

As it can be seen from the presented data, in patients with CEBV with established hyporeactive type of immune reaction (1 group) the parameters of main clinical symptoms were characterized with the less duration comparing with analogous parameters in patients with dissociative type (2 group) on the background of antiviral therapy.

Thus, the general weakness in patients with dissociative type of immune reaction was $-5,6 \pm 1,2$ days, respectively $(p<0,05)$. Arthralgia and myalgia phenomena were also less expressed in the group of patients with hyporeactive type of immune reaction and were 4,6 $\pm 0,9$ and $8,9 \pm 1,0$ days, respectively. The duration of peripheral lymphodenopathy was also less in patients with hyporeactive type of immune reaction: $4,8 \pm 1,1$, comparing with the data of patients with dissociative type $-9,7 \pm 1,2(p<0,05)$. Subfebrility was reliably shorter in patients with hyporeactive type of immune reaction $(5,9 \pm 1,8$ days) comparing with parameters at dissodiative type $(10,4 \pm 1,4$ days $),(p<0,05)$. Hepatolienal syndrome was the most prolonged clinical symptom in patients with CEBV with both hyporeactive $(18,8 \pm 2,2$ days), and dissociative $(26,5 \pm 2,0$ days $)$ type of immune reaction $(p<0,05)$.

\section{Discussion of results of research}

The studies of last years established that cytokine spectrum at EBV-infection depends on the balance of the links of organism immune response and the disturbance of balance of Th1/Th2 cytokines production by cells plays an important role in immunopathogenesis. The most scientists are agreed that the predominant participation of cytokines, produced by Th-2-lymphocytes, is associated with the viral persistency and chronization of process and Th-1 - with spontaneous recovery and elimination of causative agent.

Despite the significant attainments in this field, many questions as to the character of cytokine producing ability of immunocompetent cells and their immunopathogenetic features at CEBV-infection remain unexplained for today, and the literary data are not unambiguous and sufficiently grounded.

Thus, in patients with dissociative type of immune reaction was observed the low production of anti-inflammatory cytokines and regulatory IL-2, whereas the levels of proinflammatory IL-4 and IL-10 reliably increased in correspondence with the process intensity. IL-4 exceeded the parameters of control group in 5,7 times and IL-10 exceeded in 6 times the mean values of control group $(\mathrm{p}<0,05)$.

Whereas in patients with CEBV with revealed hyporeactive type of immune reaction the synthesis of proinflammatory and anti-inflammatory cytokines was characterized by the low concentrations (IL- $1 \beta$ levels varied from 25,32 to $72,19 \mathrm{pg} / \mathrm{ml}$; TNF- $\alpha$ - from 32,5 to $67,2 \mathrm{pg} / \mathrm{ml}$; IL- 6 - from 16,1 to $27,3 \mathrm{pg} / \mathrm{ml}$; IL-2 - from 35,12 to $81,1 \mathrm{pg} / \mathrm{ml}$; IL-4 - from 25,3 to $96,45 \mathrm{pg} / \mathrm{ml}$, IL-10 - from 36,34 to $99,1 \mathrm{pg} / \mathrm{ml}$ ), the parameters were practically within the values of the control group and were not statistically reliable $(\mathrm{p}>0,05)$. 
The researchers, directed on medicamental correction of the revealed disorders at the given types of immune reaction in patients with CEBV and on the study of their influence on the clinical outcome, are interesting and will be the subject of our further investigations.

\section{Conclusions}

The received results of researches prove the existence of cytokine imbalance at EBV-infection, and establish dissociative and hyporeactive types of immune reaction, testifying to the inadequate cellular-humoral reactivity of organism under conditions of EBV prolonged persistency that is manifested by inclination to suppression of cellular-mediated and intensification of humoral mechanisms of immune response and is reflected in clinical-biochemical manifestations of disease that results in prolonged wavy course.

Just the functional imbalance of immunity links to the priority of Tx 2 type, which biological effects are directed on the limitation of intensity and prevalence of inflammatory process in different organs, favors the prolongation of viral persistency.

\section{References}

[1] Krasnickaya, A. S., Borovskaya, N. A. (2012). Immunologicheskie aspekty hronicheskogo tonzillita, associirovannogo s virus EHpshtejna-Barra infekciej. Fundamental'nye issledovaniya, 4-2, 299-305.

[2] Gorejko, T. V., Kalinina, N. M., Drygina, L. B. (2011). Rol' citokinov v patoeneze hronicheskoj infekcii, vyzvannoj virusom EHpshtejna-Barr. Citokiny i vospalenie, 4, 44-49.

[3] Naslednikova, I. O., Novickij, V. V., Urazova, O. I., Gorbunova, U. B., Suhalenceva, N. A., Chernov, A. S., et. al. (2009). Allel'nyj polimorfizm genov IL-2 i IL-4 pri gerpes-virusnoj infekcii. Klinicheskaya laboratornaya diagnostika, 7, 39-42.

[4] Ketlinskij, S. A., Simbircev, A. S. (2008). Citokiny. Sankt-Peterburg: OOO «Izdatel'stvo Foliant», 552 .

[5] Kravchenko, I., Fazylov, V. H., Semenov, V. V. (2010). Nestabil'nost' kletochnogo genoma pri patologicheskih sostoyaniyah infekcionnogo geneza. EHpidemiologiya i infekcionnye bolezni, 4, 46-50.

[6] Abend, J. R., Ramalingam, D., Kieffer-Kwon, P., Uldrick, T. S., Yarchoan, R., Ziegelbauer, J. M. (2012). Kaposi's Sarcoma-Associated Herpesvirus MicroRNAs Target IRAK1 and MYD88, Two Components of the Toll-Like Receptor/Interleukin-1R Signaling Cascade, To Reduce InflammatoryCytokine Expression. Journal of Virology, 86 (21), 11663-11674. doi: 10.1128/jvi.01147-12

[7] Cen, O., Longnecker, R. (2015). Latent Membrane Protein 2 (LMP2). Current Topics in Microbiology and Immunology, 151-180. doi: 10.1007/978-3-319-22834-1_5

[8] Fish, K., Chen, J., Longnecker, R. (2014). Epstein-Barr virus latent membrane protein 2A enhances MYC-driven cell cycle progression in a mouse model of B lymphoma. Blood, 123 (4), 530-540. doi: 10.1182/blood-2013-07-517649

[9] Fotheringham, J. A., Coalson, N. E., Raab-Traub, N. (2012). Epstein-Barr virus latent membrane protein-2A induces ITAM/Syk- and Aktdependent epithelial migration through alphav-integrin membrane translocation. Journal of Virology, 86 (19), 10308-10320. doi: 10.1128/jvi.00853-12

[10] Fukuda, M., Kawaguchi, Y. (2014). Role of the immunoreceptor tyrosine-based activation motif of latent membrane protein 2A (LMP2A) in Epstein-Barr virus LMP2A-induced cell transformation. Journal of Virology, 88 (9), 5189-5194. doi: 10.1128/jvi.03714-13

[11] Griffin, B. D., Gram, A. M., Mulder, A., Van Leeuwen, D., Claas, F. H., Wang, F. et. al. (2013). EBV BILF1 evolved to downregulate cell surface display of a wide range of HLA class I molecules through their cytoplasmic tail. The Journal of Immunology, 190 (4), 1672-1684. doi: 10.4049/jimmunol.1102462

[12] Gujer, C., Chatterjee, B., Landtwing, V., Raykova, A., McHugh, D., Munz, C. (2015). Animal models of Epstein Barr virus infection. Current Opinion in Virology, 13, 6-10. doi: 10.1016/ j.coviro.2015.03.014

[13] Lindquester, G. J., Greer, K. A., Stewart, J. P., Sample, J. T. (2014). Epstein- Barr virus IL-10 gene expression by a recombinant murine gammaherpesvirus in vivo enhances acute pathogenicity but does not affect latency or reactivation. Herpesviridae, 5 (1), 1. doi: 10.1186/2042-4280-5-1 
[14] Thorley-Lawson, D. A., Hawkins, J. B., Tracy, S. I., Shapiro, M. (2013). The pathogenesis of Epstein-Barr virus persistent infection. Current Opinion in Virology, 3 (3), 227-232. doi: 10.1016/ j.coviro.2013.04.005

[15] Xiao, L., Hu, Z. Y., Dong, X., Tan, Z., Li, W., Tang, M. et. al. (2014). Targeting Epstein-Barr virus oncoprotein LMP1-mediated glycolysis sensitizes nasopharyngeal carcinoma to radiation therapy. Oncogene, 33 (37), 4568-4578. doi: 10.1038/onc.2014.32

[16] Zuo, J., Quinn, L. L., Tamblyn, J., Thomas, W. A., Feederle, R., Delecluse, H.-J. et. al. (2010). The Epstein-Barr virus-encoded BILF1 protein modulates immune recognition of endogenously processed antigen by targeting major histocompatibility complex class I molecules trafficking on both the exocytic and endocytic pathways. Journal of Virology, 85 (4), 1604-1614. doi: 10.1128/jvi.01608-10

[17] Kirillova, T. V. (2013). Pokazateli citokinovogo profilya u bol'nyh limfomami. BMIK, 3, 525.

[18] Kurtasova, L. M., Shmidt, A. R. (2011). Izmeneniya fenotipa i funkcional'no-metabolicheskoj aktivnosti immunokompetentnyh kletok krovi u detej rannego vozrasta s virus EHpshtejna-Barr-infekciej. Epidemiologiya i infekcionnye bolezni, 2, 36-40.

[19] Domnikova, N. P., Petrusenko, E. E., Reshetnikov, O. V., Ryzhikova, S. L., Varaksin, N. A. (2010). Uroven' syvorotochnyh citokinov pri limfoproliferativnyh zabolevaniyah. Novosti «Vektor-Best», 2 (56), 4-7.

[20] Martin, K. A., Lupey, L. N., Tempera, I. (2016). Epstein-Barr Virus Oncoprotein LMP1 Mediates Epigenetic Changes in Host Gene Expression through PARP1. Journal of Virology, 90 (19), 8520-8530. doi: 10.1128/jvi.01180-16

[21] Nagoev, B. S., Nagoeva, M. H., Kambachokova, E. A. (2011). O roli citokinov v regulyacii immunnoj sistemy pri infekcionnyh zabolevaniyah. Infekcionnye bolezni, 9 (1), 260. 